\title{
Raptor habitat use in the Lake Chad Basin: insights into the effect of flood-plain transformation on Afrotropical and Palearctic raptors
}

\author{
RALPH BUIJ and BARBARA M. CROES
}

\section{Summary}

West African flood-plains have undergone major land-use transformations in the second half of the $2 \mathrm{O}^{\text {th }}$ century. To obtain insight in the effect of flood-plain development for irrigated rice cultivation on the abundance, richness, and diversity of Palearctic and Afrotropical raptors, we conducted monthly transect surveys covering dry and wet seasons in four major habitats on the Waza-Logone flood-plain of Cameroon: dry grasslands, cultivated grasslands, rice fields, and seasonally flooded grasslands resembling natural flood-plain vegetation. We recorded 36 raptor species among 2,533 individuals, dominated by Black Kite Milvus migrans, which comprised $42 \%$ of counts. Although richness and diversity were not related to land-use for Palearctic raptors, Afrotropical raptor diversity was higher on the flooded grasslands compared to the newly created cultivated habitats and dry grasslands. The abundance of Afrotropical raptors did not significantly differ across habitats but was lower in rice-fields when Black Kite and Hooded Vulture Necrosyrtes monachus were excluded. Conversely, Palearctic raptor abundance was highest in post-harvest rice fields, demonstrating the importance of the rice fields as foraging habitat for Palearctic raptors. Further transformation of West Africa's flood-plains is expected, reducing their capacity for Afrotropical raptors, while Palearctic raptors may benefit from expansion of rice-fields, but more research is needed on their vulnerability to pesticide use.

\section{Résumé}

Les plaines d'inondation de l'Afrique de l'Ouest ont subi d'importantes transformations dans la deuxième moitié du xxe siècle, notamment pour le développement de la culture du riz irrigué. Pour évaluer l'effet de ces transformations sur l'abondance, la richesse et la diversité des rapaces paléarctiques et africains, nous avons effectué des comptages mensuellement, couvrant les saisons sèches et humides dans quatre types d'habitats de la plaine du bas Logone, au nord Cameroun: les plaines sèches, les plaines cultivées, les rizières, et les plaines saisonnièrement inondées, ressemblant à la végétation originale. Nous avons enregistré 36 espèces de rapaces parmi 2,533 individus, dominés par Milvus migrans, qui représente $42 \%$ des effectifs. Bien que la richesse et la diversité n'étaient pas liée au type d'habitat pour les rapaces paléarctiques, la diversité des espèces africaines était plus élevée sur les plaines inondées par rapport aux habitats cultivés et aux plaines sèches. En plus, l'abondance des rapaces africains était plus faible dans les rizières quand Milvus migrans et Necrosyrtes monachus ont été exclus. Au contraire, l'abondance des rapaces paléarctiques était la plus élevée dans les rizières, montrant l'importance des champs de riz pour ce groupe en saison sèche et post-récolte. De nouvelles transformations des plaines inondées sont prévues, qui peuvent mener à la réduction de leur capacité d'acceuil pour les rapaces africains, 
tandis que les rapaces paléarctiques pourraient en bénéficier grâce à l'extension des rizières, mais plus de recherche est nécessaire sur leur vulnérabilité face à l'utilisation des pesticides.

\section{Introduction}

Raptors are generally recognised as being sensitive to environmental change triggered by anthropogenic causes (Sergio et al. 2006, 2008), but moderate habitat alteration may positively influence raptor diversity and abundance if it coincides with increased foraging and nesting availability (Rodríguez-Estrella et al. 1998, Sánchez-Zapata and Calvo 1999). However, increasingly rapid processes of urbanisation and agricultural intensification in developing countries may negate the adaptive response of raptors to semi-natural habitats created over longer periods by humans (Carrete and Donázar 2005). In West Africa, the seasonally flooded grasslands of the Senegal River Delta, the Inner Niger Delta, the Lake Chad Basin, and their associated river systems are prime examples of habitats which have been rapidly and dramatically altered by developments aimed at fulfilling the needs of growing human populations (Zwarts et al. 2009). Embanking many West African flood-plains in the second half of the $20^{\text {th }}$ century for the development of rice irrigation schemes preceded the conversion of highly productive, seasonally inundated grasslands into semi-natural habitats dominated by desiccated grasslands, cultivated fields, and human habitation. Such developments severely impacted flood-plain dynamics, significantly depressing their productivity and associated wildlife populations (Loth 2004, Zwarts et al. 2009). Raptors were correspondingly affected, their declines in the West African inundation zones being among the most severe in a vast region of central West Africa between 1973 and 2004 (Thiollay 2001, 2006).

Despite the great importance of West Africa's flood-plains and their associated cultivated habitats to raptor populations, particularly Palearctic raptors (Thiollay 1989), their utilisation by raptors has been relatively little studied (Thiollay 1978, Zwarts et al. 2009). In the absence of studies on habitat use, it is unclear how habitat transformation of flood-plains may have impacted Afrotropical and Palearctic raptors. Our aim here was to examine habitat use by raptors on the Waza-Logone flood-plain in northern Cameroon, in order to evaluate the effect of flood-plain habitat modification on the abundance, diversity and richness of Afrotropical and Palearctic raptor assemblages. Since distribution patterns of raptor populations in West Africa are highly dynamic due to almost continuous displacement in response to seasonal rains and changes in prey availability (Thiollay 1989), our assessment included monthly counts incorporating dry and wet seasons. Based on previous findings (Thiollay 2001, 2006, Anadón et al. 2010), we predicted that the habitats least affected by development and human exploitation, i.e. seasonally flooded grasslands and dry, protected grasslands, are preferred over cultivated habitats by Afrotropical raptors, indicated by their greater abundance, diversity and richness. Conversely, Palearctic raptors have been shown to be generally less sensitive to human exploitation, readily foraging over disturbed and cultivated habitats (Herremans and Herremans-Tonnoeyr 2000, Buij et al. 2012, Limiñana et al. 2012). For this reason, the abundance, diversity and richness of Palearctic raptors was expected to be greater in transformed grasslands with sorghum- and rice-fields, which harbour abundant and easily accessible rodent prey (Poulet 1985, Buij et al. 2012), compared to flooded or dry grasslands.

\section{Methods}

\section{Study area}

The study area was situated in the Waza-Logone flood-plain of the Far North of Cameroon, in the inundation zone of the Logone River, which is part of the more extensive Lake Chad Basin $\left(10^{\circ} 15^{\prime} \mathrm{N}-11^{\circ} 55^{\prime} \mathrm{N}\right.$ and $14^{\circ} 24^{\prime} \mathrm{E}-15^{\circ} 15^{\prime} \mathrm{E}$; Figure 1 ). The Waza-Logone flood-plain is located in the transition zone between the Sudan and Sahel climatic zones in Cameroon and encompasses desiccated and flooded grasslands, open savanna woodland, and cultivation, notably rice and dry-season sorghum. The area was designated a Wetland of International Importance by the Ramsar Convention in 2006, for its important wildlife concentrations including migratory and African wetland birds. 


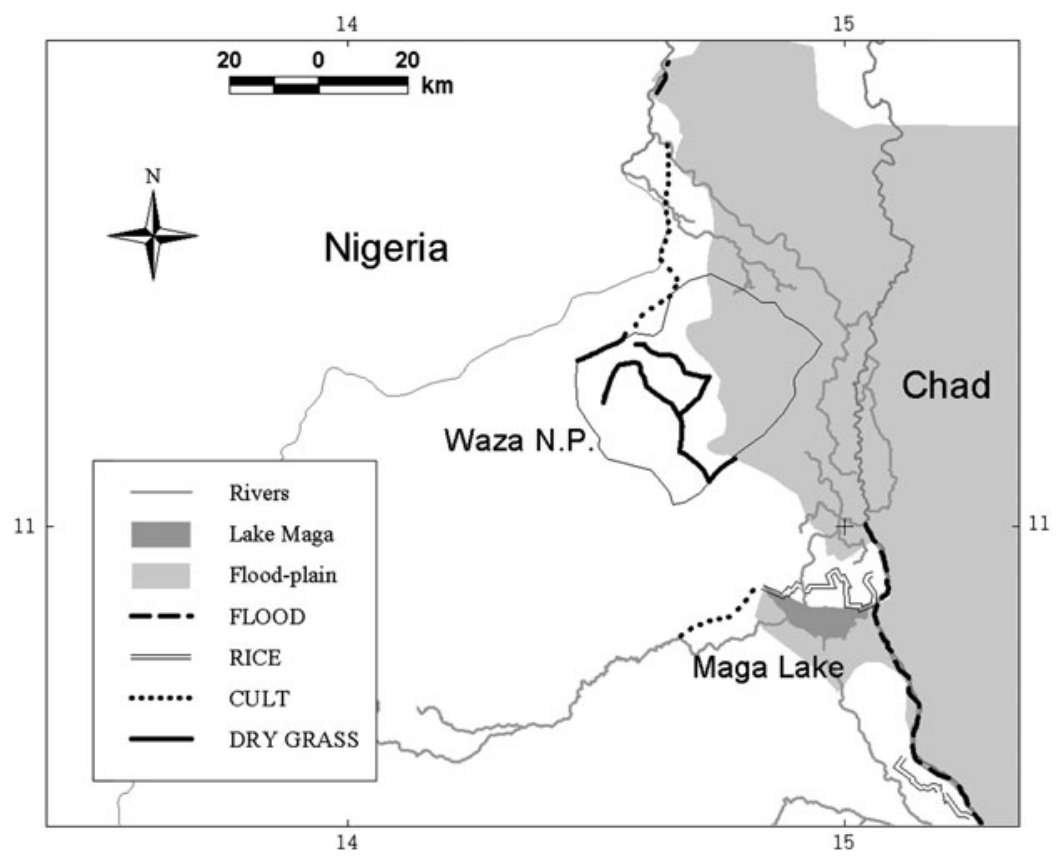

Figure 1. Location of roads used for transect surveys in the Lake Chad Basin of northern Cameroon.

Part of the flood-plain is protected in the Waza National Park, proclaimed as Biosphere Reserve in 1979 (WCMC 1983). Lake Maga, an artificial wetland resulting from the construction of the Maga dam, the Logone flood-plains and Waza National Park are Important Bird Areas (BirdLife International $2012 \mathrm{a}, \mathrm{b}, \mathrm{c})$. The climate is semi-arid, with rains peaking between June and September (c.500-600 mm per annum).

The flood-plains are situated along the Logone River, largely east and north of Waza National Park, with a surface area of $8,000 \mathrm{~km}^{2}$ in Cameroon. The inundation in the Waza-Logone flood-plain extends from August to November in average years, and duration, depth and extent of flooding is much lower during dry years (Scholte et al. 2000). An earthen dam was constructed along the Logone River in 1979 to allow the development of a rice irrigation scheme with $70 \mathrm{~km}^{2}$ of rice-fields, reducing flooding on $1,500 \mathrm{~km}^{2}$ of the flood-plain. The negative impact on the ecology of the plains, its grass species composition and biomass, herbivore and bird populations was partly rectified in 1994 through the breaching of the dam just north of the rice-fields (Loth 2004). The ecological success from the partial re-flooding of the desiccated plains triggered human immigration into the area, leading among other things to a threefold increase in livestock numbers (Scholte 2003). The dry plains are used for sorghum cultivation in the dry season (October-March), when rice-fields are mostly inactive, partly burnt, and grazed by livestock. The flood-plains are home to antelope populations, such as kob Kobus kob and topi Damaliscus korrigum, mostly inside the national park. Since the mid-196os their numbers have declined by $94 \%$ and $96 \%$, respectively, following droughts, the damming of the Logone River, and, more recently, poaching inside the park.

\section{Habitat types}

To obtain insight into the effect of flood-plain transformation on the abundance, richness, and diversity of Palearctic and Afrotropical raptors, we conducted surveys along transects in four major flood-plain 
habitat types. Landsat MSS satellite images in combination with field observations were used to distinguish between major habitat types differing in degree of transformation and productivity:

I) Dry grasslands (DRY GRASS). Largely desiccated flood-plain with woodlands on higher ground, located entirely inside Waza National Park. The habitat is dominated (95\%) by Sclerocarya birrea on higher ground and Acacia seyal on black clay soils which become saturated with water during the rainy season and which are covered in annual herbs and grasses such as Sorghum arundinaceum. Sections of the habitat (2-25\%) are still inundated from August to November but the area affected by inundation and the depth of floodwaters declined considerably with the construction of the Lake Maga dam. Numerous artificial and natural waterholes surrounded by Tamarindus indica and Balanites aegyptiaca trees hold water until the second half of the dry season;

2) Cultivated grasslands (CULT). Located outside the park. Similar habitat as above, a desiccated flood-plain dominated by Acacia seyal trees and numerous pools surrounded by stands of Tamarindus indica and Balanites aegyptiaca, and some flooded areas during the wet season. Wood cutting has reduced woody plant cover, notably Acacia seyal. This area is interspersed by traditionally cultivated dry-season sorghum in so-called "karal fields" (c.30\% of total land cover), and few villages;

3) Irrigated rice-fields (RICE). Located north of the Lake Maga dam and along the Logone River, rice fields make up $>85 \%$ of the surveyed habitat. The area is no longer subject to seasonal flooding. Reedbeds (Typha), small shrubs (Mitragyna, Acacia, Ziziphus) and annual grasses and herbs fringe the lake and the network of canals that border the irrigated rice-fields. Scattered karal fields remain in between the rice-fields $(<0.05 \%$ of the surface area). Rice is cultivated biannually, in April-June and August-October, and harvested in June and October. Rice-fields are largely dry between October and March, when fires and grazing further reduce the remaining rice stubble and sparse herbaceous cover. Most trees have been removed to prevent breeding of Red-billed Queleas Quelea quelea apart from stands of Azadirachta indica and Eucalyptus around numerous villages and a few palms (Hyphaene thebaica, Borassus aethiopum), larger Acacia and Faedherbia albida trees;

4) Seasonally flooded grasslands (FLOOD). The habitat is dominated (65\%) by grassy plains, which are partly flooded from August to November and covered with perennial grasses such as Echinochloa pyramidalis, Oryza longistaminata, Hyparrhenia rufa and Vetiveria nigritana (Scholte et al. 200o). Part of the habitat (c.35\%) consists of raised and non-flooded areas with mature Faedherbia albida, Hyphaene thebaica and Borassus aethiopum among small-scale cultivation and scattered human settlements (permanent and temporary).

\section{Survey methods}

Raptor surveys were performed along ten transects of $2 \mathrm{~km}$ each, totalling $20 \mathrm{~km}$ in each of the four major habitat categories (Figure 1). First, the entire road network in the study area was mapped, after which dirt and tar roads which were known to be navigable for at least 1o months of the year were selected. In all habitats $70-90 \mathrm{~km}$ of navigable roads were identified. To reduce autocorrelation between them, transects were allocated in each habitat type using randomly generated GPS locations on the navigable road network in ArcView GIS 3.2 software (ESRI 1999) and the linear distance from the end of one transect to the start of the next was held at min $2 \mathrm{~km}$ and max $4 \mathrm{~km}$. As raptor habitat utilisation is likely to vary seasonally due to effects of cultivation, grazing, floods, fires, and rains, surveys were repeated at monthly intervals, and each transect was surveyed once per month between October 2007 to July 2008 for a total of 10 surveys for each transect (i.e. $800 \mathrm{~km}$ driven in total). Surveys were conducted during the first ten days of each month and consisted of a combination of road surveys from a driving vehicle, and spot counts to assess raptor presence along transects, with the two observers each scanning one side of the transect. 
While road surveys have proven useful for comparisons of raptor community composition between habitats (Fuller and Mosher 1981, Bibby et al. 1992), they were combined with spot counts because these enhance detectability of raptors hunting on the wing (Herremans and Herremans-Tonnoeyr 2000). We incorporated a 3-min spot count halfway along each $2-\mathrm{km}$ transect, during which both observers scanned for raptors. To standardise count efforts, the total time spent surveying a $2-\mathrm{km}$ transect was held at c.15 min. Surveys were conducted only in fine weather, i.e. clear or slightly cloudy skies with low to moderate winds, starting at o6h3o to o $\mathrm{h}_{30}$ depending on the season (and the increase in air temperature). Transect surveys for a single habitat type were always conducted within three hours including time to traverse distances between transects, thus covering peak activity hours of all recorded species. All diurnal raptors perched or flying within eyesight range, on either side of the road and during spot counts were recorded with a GPS and identified with $10 \times 42$ binoculars. GPS positions were taken of birds perpendicular to the transect line, thus raptors detected beyond either end of the transect were not included. The perpendicular distance from the road to each perched or flying raptor at the location of initial detection was measured with a calibrated rangefinder, which enabled estimation of the effective strip width (ESW; Buckland et al. 1993) to evaluate potential differences in raptor detectability between habitat categories which would confound comparisons of relative abundance between habitats. To examine changes in herbaceous cover which affects foraging site selection in raptors by influencing prey accessibility (Preston 1990), the percentage cover of the rooted herbaceous vegetation along transects was characterised at $1-\mathrm{km}$ intervals using a nested 2-ha plot centred on the road.

\section{Palearctic and Afrotropical raptors}

Data were pooled for Palearctic migrants and Afrotropical species according to the breeding range of the majority of individuals making up the populations in the region (Thiollay 1977). Palearctic migrants are species which breed in Eurasia or Northern Africa and spend the Palearctic non-breeding season in sub-Saharan Africa (juveniles of various species also spend the northern breeding season in the Sahel; Thiollay 1977). Afrotropical species were recorded in the area during a large part of the year (timing different per species) and many were recorded breeding, including those species with long- (e.g. Wahlberg's Eagle Aquila wahlbergi; Meyburg et al. 1995) and short-distance seasonal displacements (Grasshopper Buzzard Butastur rufipennis), and/or nomadic movements (e.g. Black-winged Kite Elanus caeruleus; Thiollay 1977). Black Kite Milvus migrans populations were composed of Afrotropical Yellow-billed Kites (M. m. parasitus/aegyptius; Johnson et al. 2005) and Palearctic Black Kites (M. m. migrans) and the two races could not be safely distinguished most of the time. However, the majority of individuals identified $(>98 \%)$ referred to M. m. parasitus/aegyptius and Black Kite was therefore treated as an Afrotropical raptor.

\section{Data analysis}

To determine whether detectability of raptors differed between habitat categories, we calculated ESW for raptors in each habitat category using Distance 6.0 software (Thomas et al. 2006). Raptors were grouped into three size categories based on mean adult body mass (small: $<300 \mathrm{~g}$, medium: 300-800 g, large: $>800$ g; Ferguson-Lees and Christie 2001) assumed to have approximately comparable detectability. To determine ESW separately for each raptor size category, six combinations of key functions with expansion series were used to model the detection functions: the half-normal key function with cosine and hermite polynomial adjustment terms, the hazardrate key function with cosine and simple polynomial, and the uniform key function with cosine and simple polynomial. Following Buckland et al. (1993), models with the lowest Akaike Information Criterion (AIC) value were selected for estimation of ESW and significant differences of ESW between habitats for each size category were based on overlap of $95 \%$ confidence intervals. 
For comparing richness and diversity of the raptor assemblage between habitat categories, we used sample-based rarefaction, which allowed for the statistically robust comparisons based on equivalent numbers of individuals and samples (Colwell et al. 2004). Sample-based rarefaction computes the expected number of species when samples are drawn at random (without replacement) from a set of samples that are collectively representative of an assemblage (Gotelli and Colwell 2001). We used the cumulative species number on the $2-\mathrm{km}$ transects $(n=10$ in each category) as our units of replication. The Mao Tau estimator of rarefied species richness (Mao et al. 2005) was used to compute rarefaction curves in EstimateS Version 8.o software (Colwell 2006). Samples were randomised 50 times for each dataset. We standardised comparisons by comparing expected species numbers at equal effort (i.e. similar number of individuals observed; Gotelli and Colwell 2001). Differences in species diversity were compared in EstimateS using Shannon diversity estimates, which weighs species proportionately to their frequencies in the sample rather than favouring common or rare species such as species richness or other diversity indices (e.g. Simpson's index; Jost 2006). We used sampling with replacement which allowed estimation of confidence intervals and comparisons of diversity between habitats sampled at equal effort. The criterion used to determine whether the richness and diversity estimations were significantly different $(P<0.05)$ was the absence of overlap among the $95 \%$ confidence intervals for richness estimates (Colwell et al. 2004).

Generalized Estimated Equations (GEEs) with binomial errors were used to analyse the distribution of the most common species among the four main habitat types in SPSS 19.0 (SPSS Inc, Chicago, IL). GEEs are an extension of Generalized Linear Models that allow the analysis of correlated data arising from repeated measures (in the binomial model: monthly species presence on $2-\mathrm{km}$ transect segments; Hardin and Hilbe 2003). Thus, habitat (four categories: DRY GRASS, CULT, RICE, FLOOD) was fitted as the predictor variable and binomial presence data for each species as dependent variables. The $2-\mathrm{km}$ segments in each habitat category were taken as subject variables with months $(n=10)$ as within-subject variables. We specified independent or first-order autoregressive (AR-1) covariance types to account for potential temporal autocorrelation between subsequent transect surveys. Apart from binomial models to test species presence, we investigated associations between habitat and the abundance of all raptors, Afrotropical raptors, and Palearctic raptors on 2-km transects using GEEs with Poisson and Negative Binomial errors and log link functions. Final model selection was based on quasi-likelihood under the independence model criterion (QIC; Hardin and Hilbe 2003). Differences between habitats for all models were tested using pair-wise comparisons in GEE and considered significant at $P<0.05$ but adjustments were made for Type I error using Bonferroni correction. Kruskal-Wallis tests were used to explore differences in mean monthly grass cover values between the four main habitat types. For all analyses, tests are two-tailed and statistical significance was set at $\alpha<0.05$.

\section{Results}

In total 36 species were recorded during surveys (Table 1 ). Thirty-six percent of those (13 species) were Palearctic migrants, which constituted $19 \%$ of the total number of raptors observed $(n=2,533)$. Black Kites, which included only a small percentage of Palearctic origin (Table 1 ), comprised $42 \%$ of all raptors and $51 \%$ of Afrotropical raptors detected. Other common raptors were Hooded Vulture Necrosyrtes monachus (11\% of total numbers), Grasshopper Buzzard (9\%), and Western Marsh-harrier Circus aeruginosus (8\%). Species diversity had clear patterns related to habitat categories only for Afrotropical raptors (Figure 2a), with a significantly higher diversity on seasonally flooded grasslands compared to other habitats. Grass cover also differed between habitat categories $\left(\chi_{3}^{2}=8.48, P<0.05\right)$, and was significantly higher in the floodplain than in the other habitats. Conversely, Palearctic raptor diversity and diversity of the entire raptor assemblage did not differ significantly across habitats. Further, no significant differences in species richness were recorded between habitat categories for overall, Afrotropical, and Palearctic raptor richness (Figure $2 b$ ). 
Table 1. Total number of raptors detected on 10 2-km transects surveyed at monthly intervals between October 2007 and July 2008 in the partly cultivated grasslands (CULT), dry grasslands (DRY GRASS), rice-fields (RICE), and seasonally flooded grasslands (FLOOD). Numbers are presented separately for the wet (four counts; May-Oct) and dry season (six counts; Nov-April).

\begin{tabular}{|c|c|c|c|c|}
\hline CULT & $\begin{array}{l}\text { DRY } \\
\text { GRASS }\end{array}$ & RICE & FLOOD & \\
\hline Dry Wet & Dry Wet & Dry Wet & Dry Wet & Total \\
\hline
\end{tabular}

\section{Palearctic raptors}

Western Marsh-harrier Circus aeruginosus

Booted Eagle Hieraaetus pennatus

Common Kestrel Falco tinnunculus

Steppe Eagle Aquila nipalensis

Long-legged Buzzard Buteo rufinus

Montagu's Harrier Circus pygargus

Pallid Harrier Circus macrourus

Short-toed Snake-eagle Circaetus gallicus

Lesser Kestrel Falco naumanni

Osprey Pandion haliaetus

Barbary Falcon Falco pelegrinoides

Red-footed Falcon Falco vespertinus

Egyptian Vulture Neophron percnopterus

$\begin{array}{ccccccccr}13 & 13 & 18 & 8 & 94 & 3 & 49 & 0 & 198 \\ 7 & 0 & 11 & 0 & 62 & 0 & 11 & 0 & 91 \\ 16 & 0 & 11 & 0 & 13 & 0 & 5 & 0 & 45 \\ 1 & 0 & 3 & 0 & 33 & 0 & 3 & 0 & 40 \\ 2 & 0 & 1 & 0 & 20 & 0 & 3 & 0 & 26 \\ 6 & 0 & 3 & 0 & 12 & 0 & 5 & 0 & 26 \\ 2 & 0 & 2 & 1 & 16 & 0 & 1 & 0 & 22 \\ 3 & 1 & 6 & 0 & 5 & 0 & 2 & 0 & 17 \\ 2 & 0 & 2 & 0 & 0 & 0 & 0 & 0 & 4 \\ 0 & 0 & 0 & 0 & 1 & 0 & 3 & 0 & 4 \\ 2 & 0 & 0 & 0 & 0 & 0 & 0 & 0 & 2 \\ 0 & 1 & 0 & 0 & 0 & 0 & 0 & 0 & 1 \\ 0 & 0 & 1 & 0 & 0 & 0 & 0 & 0 & 1\end{array}$

\section{Afrotropical raptors}

Black Kite Milvus migrans ${ }^{1}$

Hooded Vulture Necrosyrtes monachus

Grasshopper Buzzard Butastur rufipennis

Dark Chanting-goshawk Melierax metabates

White-backed Vulture Gyps africanus

African Swallow-tailed Kite Chelictinia riocourii

Black-winged Kite Elanus caeruleus

Tawny Eagle Aquila rapax

Gabar Goshawk Micronisus gabar

Lanner Falcon Falco biarmicus

Wahlberg's Eagle Aquila wahlbergi

Red-necked Falcon Falco chicquera

Rueppell's Vulture Gyps rueppellii

African Fish-eagle Haliaeetus vocifer

Bateleur Terathopius ecaudatus

Long-crested Eagle Lophaetus occipitalis

Shikra Accipiter badius

Beaudouin's Snake-eagle Circaetus beaudouini

Brown Snake-eagle Circaetus cinereus

Grey Kestrel Falco ardosiaceus

African Harrier-hawk Polyboroides typus

Secretarybird Sagittarius serpentarius

Lappet-faced Vulture Torgos tracheliotus

\begin{tabular}{rrrrrrrrr}
191 & 22 & 299 & 45 & 388 & 3 & 78 & 27 & 1053 \\
1 & 0 & 0 & 1 & 15 & 3 & 170 & 91 & 281 \\
97 & 66 & 43 & 28 & 1 & 0 & 4 & 0 & 239 \\
9 & 2 & 16 & 3 & 10 & 12 & 35 & 25 & 112 \\
1 & 0 & 3 & 0 & 1 & 0 & 37 & 18 & 60 \\
13 & 1 & 39 & 0 & 1 & 0 & 3 & 0 & 57 \\
2 & 1 & 7 & 1 & 22 & 8 & 5 & 10 & 56 \\
4 & 3 & 12 & 5 & 2 & 1 & 4 & 3 & 34 \\
3 & 2 & 5 & 2 & 0 & 4 & 10 & 8 & 34 \\
13 & 4 & 6 & 3 & 1 & 0 & 0 & 2 & 29 \\
0 & 1 & 3 & 5 & 5 & 3 & 10 & 0 & 27 \\
1 & 0 & 1 & 0 & 4 & 1 & 11 & 9 & 27 \\
0 & 0 & 0 & 2 & 2 & 0 & 7 & 1 & 12 \\
0 & 0 & 6 & 2 & 0 & 0 & 1 & 1 & 10 \\
0 & 0 & 2 & 6 & 0 & 0 & 2 & 0 & 10 \\
0 & 1 & 1 & 0 & 0 & 1 & 3 & 0 & 6 \\
0 & 0 & 1 & 1 & 0 & 0 & 1 & 0 & 3 \\
1 & 0 & 0 & 0 & 0 & 0 & 0 & 0 & 1 \\
0 & 0 & 0 & 1 & 0 & 0 & 0 & 0 & 1 \\
0 & 0 & 0 & 0 & 0 & 0 & 0 & 1 & 1 \\
1 & 0 & 0 & 0 & 0 & 0 & 0 & 0 & 1 \\
0 & 0 & 0 & 0 & 0 & 0 & 0 & 1 & 1 \\
0 & 0 & 1 & 0 & 0 & 0 & 0 & 0 & 1 \\
391 & 118 & 503 & 114 & 708 & 39 & 463 & 197 & 2,533 \\
23 & 13 & 26 & 16 & 21 & 10 & 25 & 13 & 36 \\
\hline
\end{tabular}

Total individuals

Species number

${ }^{1}$ A proportion of Black Kites Milvus migrans (c.1-2\% of numbers between October-March) was identified as the Palearctic subspecies migrans, the bulk constituted by the Afrotropical subspecies M. m. parasitus/ aegyptius (Yellow-billed Kite). 

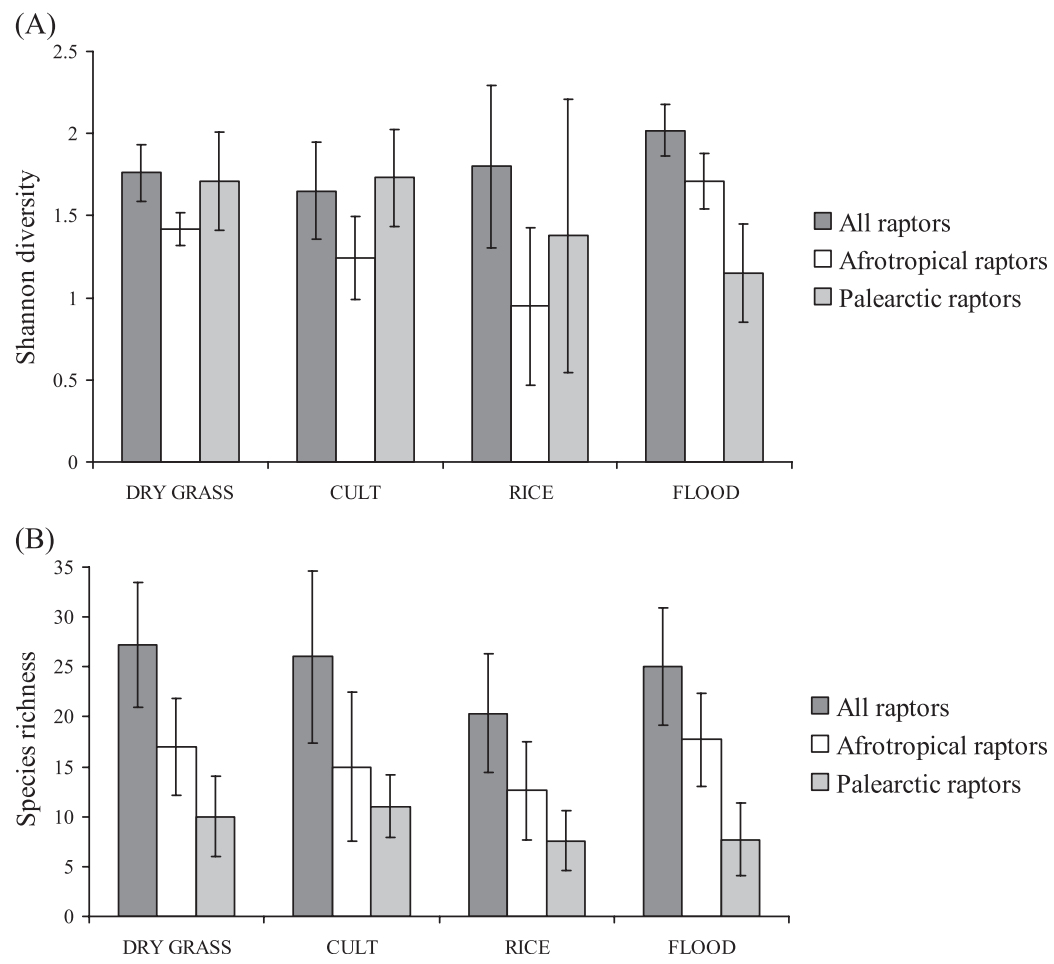

Figure 2. Raptor diversity and richness in four habitat types on the Waza-Logone flood-plain. Shannon diversity indices (A) and species richness (B) are presented for all raptors, Afrotropical raptors, and Palearctic raptors. Indices were estimated at equal sampling effort. Values are presented with $95 \%$ CIs.

Prior to examinations of species-habitat associations, estimation of ESW using Distance 6.0 showed these did not significantly differ $(P<0.05)$ between the four habitat categories for the three raptor size categories, dismissing the need for corrections of relative abundance estimates due to differences in detectability between habitats. GEE model results indicated that raptor abundance did not differ among habitats for the 10-month survey period $\left(\chi_{3}^{2}=1.81, P=0.61\right)$, which remained the case when the most abundant species, Black Kite and Hooded Vulture, to a different degree commensal with humans, were excluded from the analysis. Also, the abundance of Afrotropical species did not differ among habitats $\left(\chi_{3}^{2}=1.16, P=0.76\right)$. However, Afrotropical raptors were significantly less abundant in rice-fields compared to other habitats when Black Kite and Hooded Vulture were excluded $\left(\chi_{3}^{2}=32.7, P<0.001\right)$. Conversely, Palearctic migrants were significantly more abundant in rice-fields compared to other habitats $\left(\chi_{3}^{2}=51.8, P<\right.$ o.001 $)$. This was mirrored by species-specific binomial models for most common Palearctic migrants (Table 2), although no significant habitat effect on presence was detected for Montagu's Harrier Circus pygargus $\left(\chi_{3}^{2}=3.87, P=0.27\right)$, Common Kestrel Falco tinnunculus $\left(\chi_{3}^{2}=4.30, P=0.23\right)$, and Short-toed Snake-eagle Circaetus gallicus $\left(\chi_{3}^{2}=3.19, P=0.36\right)$. Raptors significantly associated with rice-fields over other habitats (Table 2 ) were regularly observed capturing rodents (Arvicanthis spp. and Mastomys spp.). Inspection of the combined monthly counts for these five Palearctic migrants showed that rice-fields were favoured from November (Figure 3), corresponding with a decrease in herbaceous cover. Monthly counts appeared to follow a similar 
Table 2. Relationship between raptor presence and habitat, for (A) Afrotropical and (B) Palearctic raptors. Generalized Estimating Equations with binomial errors and a logit link function were used with habitat (four categories: CULT: cultivated grasslands; DRY GRASS: dry grasslands; RICE: rice fields; FLOOD: flood-plain) fitted as predictor variable and binomial presence data for each species as dependent variables. Model fit and mean differences between habitat categories are presented after pairwise comparisons and Bonferroni correction for Type I errors. Only species for which habitat was significantly associated $(P<0.05)$ with presence are reported.

(A)

\begin{tabular}{|c|c|c|c|c|c|c|c|c|c|c|c|}
\hline \multirow[t]{2}{*}{ (I) habitat } & \multirow[t]{2}{*}{ (J) habitat } & \multicolumn{2}{|c|}{ Black Kite } & \multicolumn{2}{|c|}{$\begin{array}{l}\text { Grasshopper } \\
\text { Buzzard }\end{array}$} & \multicolumn{2}{|c|}{$\begin{array}{l}\text { Dark } \\
\text { Chanting- } \\
\text { goshawk }\end{array}$} & \multicolumn{2}{|c|}{$\begin{array}{l}\text { White-backed } \\
\text { Vulture }\end{array}$} & \multicolumn{2}{|c|}{$\begin{array}{l}\text { Black-winged } \\
\text { Kite }\end{array}$} \\
\hline & & $(\mathrm{I}-\mathrm{J})$ & SE & $(\mathrm{I}-\mathrm{J})$ & SE & $(\mathrm{I}-\mathrm{J})$ & SE & $(\mathrm{I}-\mathrm{J})$ & SE & $(\mathrm{I}-\mathrm{J})$ & SE \\
\hline \multirow[t]{3}{*}{ CULT } & DRY GRASS & $-0.22^{* *}$ & 0.06 & 0.08 & 0.07 & -0.09 & 0.05 & -0.01 & 0.02 & -0.03 & 0.03 \\
\hline & RICE & 0.02 & 0.06 & $0.40^{* * *}$ & 0.05 & -0.08 & 0.04 & 0.00 & 0.01 & $-0.17^{* * *}$ & 0.04 \\
\hline & FLOOD & 0.04 & 0.06 & $0.37^{* * *}$ & 0.05 & $-0.32^{* * *}$ & 0.06 & $-0.15^{* *}$ & 0.04 & -0.05 & 0.02 \\
\hline \multirow[t]{2}{*}{ DRY GRASS } & RICE & $0.24^{* * *}$ & 0.06 & $0.32^{* * *}$ & 0.06 & 0.01 & 0.05 & 0.01 & 0.02 & $-0.14^{* *}$ & 0.04 \\
\hline & FLOOD & $0.26^{* * *}$ & 0.06 & $0.29^{* * *}$ & 0.06 & $-0.23^{*}$ & 0.08 & $-0.14^{*}$ & 0.04 & -0.02 & 0.03 \\
\hline \multirow[t]{2}{*}{ RICE } & FLOOD & 0.02 & 0.06 & -0.03 & 0.02 & $-0.24^{* *}$ & 0.06 & $-0.15^{* *}$ & 0.04 & $0.12^{*}$ & 0.04 \\
\hline & Model fit & \multicolumn{2}{|c|}{$\begin{aligned} \chi_{3}^{2} & =26.2 \\
P & <0.001\end{aligned}$} & \multicolumn{2}{|c|}{$\begin{aligned} \chi_{3}^{2} & =54.6 \\
P & <0.001\end{aligned}$} & \multicolumn{2}{|c|}{$\begin{aligned} \chi_{3}^{2} & =27.4 \\
P & <0.001\end{aligned}$} & \multicolumn{2}{|c|}{$\begin{aligned} \chi_{3}^{2} & =21.2 \\
P & <0.001\end{aligned}$} & \multicolumn{2}{|c|}{$\begin{aligned} \chi_{3}^{2} & =21.7 \\
P & <0.001\end{aligned}$} \\
\hline \multirow[t]{2}{*}{ (I) habitat } & \multirow[t]{2}{*}{ (J) habitat } & \multicolumn{2}{|c|}{$\begin{array}{l}\text { Gabar } \\
\text { Goshawk }\end{array}$} & \multicolumn{2}{|c|}{ Lanner Falcon } & \multicolumn{2}{|c|}{$\begin{array}{l}\text { Red-necked } \\
\text { Falcon }\end{array}$} & \multicolumn{2}{|l|}{$\begin{array}{l}\text { Hooded } \\
\text { Vulture }\end{array}$} & & \\
\hline & & $(\mathrm{I}-\mathrm{J})$ & SE & $(\mathrm{I}-\mathrm{J})$ & SE & $(\mathrm{I}-\mathrm{J})$ & SE & $(\mathrm{I}-\mathrm{J})$ & SE & & \\
\hline \multirow[t]{3}{*}{ CULT } & DRY GRASS & 0.00 & 0.02 & 0.03 & 0.04 & 0.00 & 0.01 & 0.00 & 0.01 & & \\
\hline & RICE & 0.03 & 0.02 & $0.11^{* *}$ & 0.03 & -0.03 & 0.02 & $-0.08^{* * *}$ & 0.02 & & \\
\hline & FLOOD & -0.06 & 0.03 & $0.11^{* *}$ & 0.03 & $-0.13^{* * *}$ & 0.02 & $-0.49^{* * *}$ & 0.06 & & \\
\hline \multirow[t]{2}{*}{ DRY GRASS } & RICE & 0.03 & 0.02 & $0.08^{* *}$ & 0.02 & -0.03 & 0.02 & $-0.08^{* * *}$ & 0.02 & & \\
\hline & FLOOD & -0.06 & 0.03 & $0.08^{* *}$ & 0.02 & $-0.13^{* * *}$ & 0.02 & $-0.49^{* * *}$ & 0.06 & & \\
\hline \multirow[t]{2}{*}{ RICE } & FLOOD & $-0.09^{*}$ & 0.03 & 0.00 & 0.01 & $-0.10^{* *}$ & 0.03 & $-0.4 I^{* * *}$ & 0.06 & & \\
\hline & Model fit & \multicolumn{2}{|c|}{$\begin{array}{c}\chi_{3}^{2}=8.47 \\
P<0.05\end{array}$} & \multicolumn{2}{|c|}{$\begin{array}{c}\chi_{3}^{2}=12.8 \\
P<0.01\end{array}$} & \multicolumn{2}{|c|}{$\begin{array}{c}\chi_{3}^{2}=23.2 \\
P<0.001\end{array}$} & \multicolumn{2}{|c|}{$\begin{aligned} \chi_{3}^{2} & =79.8 \\
P & <0.001\end{aligned}$} & & \\
\hline
\end{tabular}

(B)

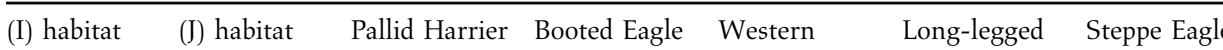
Marsh-harrier Buzzard

\begin{tabular}{|c|c|c|c|c|c|c|c|c|c|c|c|}
\hline & & & & & \\
\hline & & $(\mathrm{I}-\mathrm{J})$ & SE & $(\mathrm{I}-\mathrm{J})$ & SE & $(\mathrm{I}-\mathrm{J})$ & SE & $(\mathrm{I}-\mathrm{J})$ & SE & $(\mathrm{I}-\mathrm{J})$ & SE \\
\hline \multirow[t]{3}{*}{ CULT } & DRY GRASS & 0.00 & 0.02 & -0.04 & 0.03 & 0.00 & 0.04 & 0.01 & 0.02 & -0.02 & 0.02 \\
\hline & RICE & $-0.07^{*}$ & 0.03 & $-0.24^{* * *}$ & 0.04 & $-0.22^{* * *}$ & 0.04 & $-0.12^{* * *}$ & 0.03 & $-0.15^{* *}$ & 0.04 \\
\hline & FLOOD & 0.01 & 0.02 & -0.04 & 0.02 & -0.05 & 0.05 & 0.00 & 0.02 & -0.01 & 0.02 \\
\hline \multirow[t]{2}{*}{ DRY GRASS } & RICE & $-0.07^{*}$ & 0.03 & $-0.20^{* * *}$ & 0.04 & $-0.22^{* * *}$ & 0.04 & $-0.13^{* * *}$ & 0.03 & $-0.13^{* *}$ & 0.04 \\
\hline & FLOOD & 0.01 & 0.02 & 0.00 & 0.03 & -0.05 & 0.05 & -0.01 & 0.02 & 0.01 & 0.02 \\
\hline \multirow[t]{2}{*}{ RICE } & FLOOD & $0.08^{* *}$ & 0.02 & $0.20^{* * *}$ & 0.04 & $0.17^{* * *}$ & 0.05 & $0.12^{* * *}$ & 0.03 & $0.14^{* *}$ & 0.04 \\
\hline & Model fit & \multicolumn{2}{|c|}{$\begin{array}{r}\chi_{3}^{2}=12.5 \\
P<0.01\end{array}$} & \multicolumn{2}{|c|}{$\begin{aligned} \chi_{3}^{2} & =51.5 \\
P & <0.001\end{aligned}$} & \multicolumn{2}{|c|}{$\begin{aligned} \chi_{3}^{2} & =34.4 \\
P & <0.001\end{aligned}$} & \multicolumn{2}{|c|}{$\begin{aligned} \chi_{3}^{2} & =23.2 \\
P & <0.001\end{aligned}$} & \multicolumn{2}{|c|}{$\begin{aligned} \chi_{3}^{2} & =19.1 \\
P & <0.001\end{aligned}$} \\
\hline
\end{tabular}

$* * * P<0.001$.

$* * P<0.01$.

${ }^{*} P<0.05$. 
pattern on flooded grasslands, although numbers were lower here compared to rice-fields. In comparison, numbers of these Palearctic migrants peaked earlier in the dry season in cultivated and dry grasslands, which experienced a strong decline in herbaceous cover early in the dry season (Oct-Dec), compared to rice-fields and flooded grasslands (Figure 3).

Habitat associations for common Afrotropical raptors were more variable compared to Palearctic raptors (Table 2). Seasonally flooded grassland was favoured by generalists (Dark Chanting-goshawk Melierax metabates), bird specialists (Gabar Goshawk Micronisus gabar, Red-necked Falcon Falco chicquera), and vultures (White-backed Gyps africanus and Hooded Vulture). Conversely, dry and cultivated grasslands were more attractive than flooded grasslands and rice-fields to Lanner Falcon and Grasshopper Buzzard (Table 2), whereas Black Kite was more strongly associated with dry grasslands than other habitats. Distribution patterns for Tawny Eagle Aquila rapax $\left(\chi_{3}^{2}=5.92, P=0.12\right)$, Wahlberg's Eagle $\left(\chi_{3}^{2}=3.45, P=0.33\right)$, and African Swallow-tailed Kite Chelictinia riocourii $\left(\chi_{3}^{2}=2.56, P=0.46\right)$ were indifferent to land-use. The Black-winged Kite, a rodent specialist, was the only Afrotropical species with a preference for rice-fields (Table 2), and at least three pairs were recorded breeding in Faedherbia albida trees in rice-fields.

\section{Discussion}

Our data revealed a strikingly different distribution pattern in terms of abundance of Afrotropical and Palearctic raptors with regard to rice-fields, which were generally avoided by Afrotropical raptors but preferred by Palearctic raptors. The attractiveness of rice-fields to Palearctic raptors augments reports of raptors converging on post-harvest rice-fields in Europe (Boano and Toffoli 2002, Lourenço 2009), Asia (Fujioka et al. 2010), and the Americas (Remsen et al. 1991, Petit et al. 1999, Elphick 2004, Pandolfino et al. 2011). Evidently, the attractiveness of different habitat types may shift over the course of the winter season (cf. Figure 3), and the accessibility of rodents in rice-fields increased from November with decreasing herbaceous cover. Rodents are similarly common in sorghum fields (Buij et al. 2012), but these were localised in dry, unproductive grasslands, probably lowering their attractiveness to Palearctic raptors compared to rice-dominated

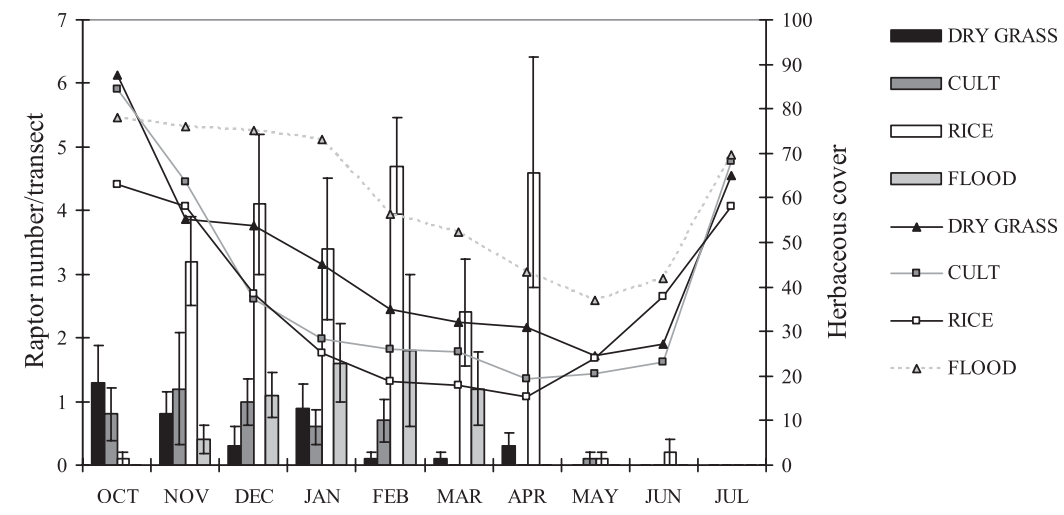

Figure 3. Mean raptor numbers $\pm \mathrm{SE}$ on 2-km transects of five Palearctic raptors (Booted Eagle, Western Marsh-harrier, Steppe Eagle, Long-legged Buzzard, Pallid Harrier) favoring rice cultivation (RICE) over cultivated grassland (CULT), dry grassland (DRY GRASS), and seasonal flood-plains (FLOOD), from October 2007 to July 2008 in the Waza-Logone flood-plain of northern Cameroon. Lines represent the mean herbaceous layer cover on $2-\mathrm{km}$ transects in each of four habitat categories during the same period. 
habitats. Intensive tree-pruning, logging, and human exploitation of tree-lined canals for fishing and bushmeat (rats, frogs) leading to high levels of human disturbance detrimental to breeding raptors (Newton 1979), explained the lack of suitability of rice-fields to Afrotropical raptors. Furthermore, rice-fields were flooded and cultivated from April, well before the arrival of the seasonal floods (August-September), limiting prey accessibility for sedentary raptors during an eight month period. Interestingly, Black-winged Kites, which are known to profit from rodent outbreaks with prolonged or variable breeding seasons (Ferguson-Lees and Christie 2001) and prefer cultivated landscapes with few trees for breeding (Balbontin et al. 2008), were the only raptors breeding among rice-fields and the only Afrotropical raptor species which increased in the area following irrigation rice scheme development (Thiollay 2001).

The situation on the original flood-plain, with its abundant wildlife and prey resources, may not be duplicated today, since the diminished productivity of the former grasslands were only partially compensated by flood-plain rehabilitation (Scholte 2005). At the same time, growing human populations, increased livestock numbers, and agricultural expansion have greatly intensified pressure on natural resources in the area (Scholte 2003), with potentially important consequences for raptor prey resources. In the absence of the original habitat, we focused our comparison on existing habitats, including the habitat most resembling the original flood-plain. This habitat differed from the newly created cultivated habitats and dry grasslands by a significantly higher grass cover, which is among the most important determinants of prey availability and foraging distribution of many raptors (Thiollay 1978), and characterised the original flood-plain (Scholte et al. 2000). The surveyed flood-plain habitat thus retained an essential component of the original grasslands, at least to foraging raptors, justifying our comparisons.

Our results revealed a greater diversity of Afrotropical raptors on the flood-plain compared to the newly created cultivated habitats and dry, protected grasslands, underlining the importance of the flood-plain to raptors. We found a preference for flood-plain habitat by five Afrotropical raptors, three of which (Dark Chanting-goshawk, White-backed Vulture, Hooded Vulture) declined significantly in the area between 1973 and 2000 (Thiollay 2001), while two others (Gabar Goshawk, Red-necked Falcon) were either too infrequently recorded to evaluate population trends, or remained stable. Although wide-ranging vultures (Kendall and Virani 2012) are likely to have been affected by practices that affected the wider region (e.g. traditional medicine trade; R. Buij, unpubl. data), these results suggest that the observed raptor declines might have at least partly been related to flood-plain embankment, which greatly reduced the extent of flood-plain habitat.

Contrary to expectations, Afrotropical raptor abundance, richness and diversity on the dry, protected grasslands was comparable to the cultivated grasslands, suggesting that the moderately affected cultivated grasslands still supported suitable habitat for many raptors. However, speciesspecific models did show variable responses, e.g. Black Kite preferred protected, dry grasslands over cultivated grasslands, whereas Lanner Falcon and Grasshopper Buzzard equally preferred dry and cultivated grasslands. These discrepancies corresponded to differences in long-term population trends between Black Kite populations (strong decrease; Thiollay 2001), and Lanner Falcon and Grasshopper Buzzard (stable), perhaps pointing to differences in species-specific sensitivity to anthropogenic impact. The observed preference for dry grasslands over flood-plain by Black Kite, Grasshopper Buzzard, and Lanner Falcon may be related to limitations on the number of breeding sites and prey availability on the flood-plain. Grasshopper Buzzard and Black Kite breed during the transition from the dry to wet seasons (March-July; R. Buij, unpubl. data) and require adequate tree cover for nesting, thus favouring well-wooded dry grasslands over the partly treeless flood-plain. In addition, prey accessibility is compromised when grass cover is high (Thiollay and Clobert 1990), as is the case during much of the year on the flood-plain.

\section{Implications for flood-plain management}

Despite their importance to Palearctic and Afrotropical birds and wildlife in general (Zwarts et al. 2009), only a small proportion of the West African flood-plains have received protected status. 
Waza National Park protects $<10 \%\left(700 \mathrm{~km}^{2}\right)$ of the Waza-Logone flood-plain, while regional protection of other flood-plain systems is limited to Djoudj and Diawling National Parks in the Senegal River Delta and various small reserves in Nigeria, Chad, and Mali. As a result, flood-plains have been vulnerable to development initiatives, and rice irrigation schemes have become a common feature of flood-plains over the past 50 years (Zwarts et al. 2009). During this period, the area planted with rice increased from 4,000 to $31,000 \mathrm{~km}^{2}$ in six Sahelian countries with large flood-plain systems (FAOSTAT 2012) and such growth is not likely to stop any time soon (Zwarts et al. 2009). Their convergence on rice-fields implies that Palearctic migrants are vulnerable to aspects pertaining to the management of the rice-fields. Firstly, any positive effect of increased prey availability can be drastically altered by changes to the flooding regime, which may negatively affect the abundance and richness of raptors (Elphick 2004). Secondly, application of harmful pesticides in rice is hardly supervised and likely to affect raptors through secondary poisoning (Mullié et al. 1991), as reported from neighbouring Chad (Keith and Bruggers 1998), but little is known about pesticide impact on raptors in the region. Deliberate, large-scale poisoning of birds for food, as reported in some East African rice schemes (Odino 2010), has not been observed in Cameroon. However, poisoning of small waterholes, already reported from the region in the 1970s (Green and Sayer 1979), is a frequently used method to harvest birds (particularly passerines) for consumption, and also kills raptors (R. Buij pers. obs.). An important recommendation emanating from this study would be a strict ban on the use of pesticides highly toxic to birds from rice fields. Instead, raptors could be promoted as valuable predators of crop-pests and assisted through supplementation of perches (Sheffield et al. 2001).

Habitat quality for Afrotropical raptors is further affected by the intensive exploitation of the Waza-Logone flood-plains and surrounding woodlands, where human disturbance, wood extraction and tree pruning progressively limit nest site availability. Poaching in Waza National Park has been on the increase since the late I99os and has decimated large wildlife populations (De Iongh et al. 2009), to the detriment of shy scavengers (e.g. Tawny Eagle, Bateleur Terathopius ecaudatus). Raptors are poached for meat and persecuted for trade (R. Buij, unpubl. data), which has contributed to declining vulture and possibly Secretarybird Sagittarius serpentarius populations. Flood-plain rehabilitation triggered a $34 \%$ increase in sedentary fishermen in two years who intensively utilise the fish resources in the park (Scholte 2003), which together with the reduced flooding extent led to declining fish stocks, weakening the prey base for the few remaining African Fish-eagle Haliaeetus vocifer pairs in the far north. Limitations to any of these exploitative utilisations will benefit raptor populations and other wildlife using the flood-plains, underlining the importance for improved protection of Waza National Park and restrictions on developments that stimulate further human immigration into the area.

\section{Acknowledgements}

This study was financially and logistically supported by the Institute of Environmental Sciences (CML) of the University of Leiden, the Netherlands, through its collaborative programme with the University of Dschang, Cameroon, at the Centre for Environment and Development Studies in Cameroon (CEDC). J-M Thiollay, H. H. de Iongh, J. Komdeur, G. de Snoo, K. Musters and an anonymous referee are thanked for comments that improved a previous manuscript.

\section{References}

Anadón, J. D., Sánchez-Zapata, J. A., Carrete, M., Donázar, J. A. and Hiraldo, F. (2010) Largescale human effects on an arid African raptor community. Anim. Conserv. 13: 495-504.

Balbontin, J., Negro, J. J., Sarasola, J. H., Ferrero, J. J. and Rivera, D. (2008) Land-use changes may explain the recent range expansion of the Black-shouldered Kite Elanus caeruleus in southern Europe. Ibis 150: 707-716.

Bibby, C. J., Burgess, N. D. and Hill, D. A. (1992) Bird census techniques. London, UK: Academic Press. 
BirdLife International (2012a) Important Bird Areas factsheet: Lake Maga. http://www. birdlife.org [accessed 20 February 2012].

BirdLife International (2012b) Important Bird Areas factsheet: Waza National Park. http://www.birdlife.org [accessed 2o February 2012].

BirdLife International (2012c) Important Bird Areas factsheet: Logone Flood plain. http:// www.birdlife.org [accessed 20 February 2012].

Boano, G. and Toffoli, R. (2002) A line transect survey of wintering raptors in the western Po Plain of northern Italy. J. Raptor Res. 36: 128-135.

Buckland, S. T., Anderson, D. R., Burnham, K. P. and Laake, J. L. (1993) Distance sampling: Estimating abundance of biological populations. London: Chapman and Hall. Buij, R., Van der Goes, D., De Iongh, H. H., Gagare, S., Haccou, P., Komdeur, J. and De Snoo, G. (2012) Interspecific and intraspecific differences in habitat use and their conservation implications for Palaearctic harriers on Sahelian wintering grounds. Ibis 154: 96-110.

Carrete, M. and Donázar, J. A. (2005) Application of central place foraging theory shows the importance of Mediterranean dehesas for the conservation of the cinereous vulture, Aegypius monachus. Biol. Conserv. 126: 582-590.

Colwell, R. K. (2006) EstimateS: statistical estimation of species richness and shared species from samples. Version 8.0 User's Guide and application.

Colwell, R. K., Mao, C. X. and Chang, J. (2004) Interpolating, extrapolating, and comparing incidence-based species accumulation curves. Ecology 85: 2717-2727.

De Iongh, H. H., Tumenta, P., Croes, B. M., Funston, P. J., Bauer, H. and Udo de Haes, H. A. (2009) Threat of lion population extinction in Waza National Park, North Cameroon. Cat News 50: 26-27.

Elphick, C. S. (2004) Assessing conservation trade-offs: identifying the effects of flooding rice fields for waterbirds on non-target bird species. Biol. Conserv. 117: 105-110.

FAOSTAT (2012) Http://faostat.fao.org. [accessed 20 March 2012].

Ferguson-Lees, J. and Christie, D. A. (2001) Raptors of the world. London, UK: Christopher Helm.
Fujioka, M., Don Lee, S., Kurechi, M. and Yoshida, H. (2010) Bird use of rice fields in Korea and Japan. Waterbirds 33: 8-29.

Fuller, M. R. and Mosher, J. A. (1981) Methods of detecting and counting raptors: A review. Studies Avian Biol. 6: 235-246.

Gotelli, N. and Colwell, R. K. (2001) Quantifying biodiversity: Procedures and pitfalls in the measurement and comparison of species richness. Ecol. Letters 4: 379-391.

Green, A. A. and Sayer, J. A. (1979) The birds of Pendjari and Arli national parks (Benin and Upper Volta). Malimbus 1: 14-28.

Hardin, J. W. and Hilbe, J. M. (2003) Generalized estimating equations. Boca Raton, Florida, US: Chapman and Hall/CRC.

Herremans, M. and Herremans-Tonnoeyr, D. (2000) Land-use and conservation status of raptors in Botswana. Biol. Conserv. 94: $31-41$.

Johnson, J. A., Watson, R. T. and Mindell, D. P. (2005) Prioritizing species conservation: does the Cape Verde kite exist? Proc. R. Soc.-Biol. Sci. 272: 1365-1371.

Jost, L. (2006) Entropy and diversity. Oikos 113: 363-375.

Keith, J. O. and Bruggers, R. L. (1998) Review of hazards to raptors from pest control in Sahelian Africa. J. Raptor Res. 32: 151-158.

Kendall, C. J. and Virani, M. Z. (2012) Assessing mortality of African vultures using wing tags and GSM-GPS transmitters. J. Raptor Res. 46: 135-140.

Limiñana, R., Soutullo, A., Arroyo, B. and Urios, V. (2012) Protected areas do not fulfill the wintering habitat needs of the trans-Saharan migratory Montagu's Harrier. Biol. Conserv. 145: 62-69.

Loth, P. (2004) The Return of the water: Restoring the Waza-Logone flood plain in Cameroon. Gland, Switzerland and Cambridge, UK: IUCN.

Lourenço, P. M. (2009) Rice field use by raptors in two Portuguese wetlands. Airo 19: $13-18$.

Mao, C. X., Colwell, R. K. and Chang, J. (2005) Estimating species accumulation curves using mixtures. Biometrics 61: 433-441.

Meyburg, B.-U., Mendelson, J. M., Ellis, D. H., Smith, D. G., Meyburg, C. and Kemp, A. C. (1995) Year-round movements of a Wahlberg's Eagle Aquila wahlbergi 
tracked by satellite. Ostrich 66: 135I40.

Mullié, W. C., Verwey, P. J., Berends, A. G., Sene, F. and Koeman, J. H. (1991) Impact of Furadan $3 \mathrm{G}$ (Carbofuran) applications on aquatic macro-invertebrates in irrigated rice in Senegal. Arch. Environ. Contamin. Toxicol. 20: 177-182.

Newton, I. (1979) Population ecology of raptors. Berkhamstead, UK: T. and A.D. Poyser.

Odino, M. (2010) Measuring the conservation threat to birds in Kenya from deliberate pesticide poisoning. Pp. 53-70 in N. Richards, ed. Carbofuran and wildlife poisoning: Global perspectives and forensic approaches. Chichester, UK: John Wiley \& Sons Ltd.

Pandolfino, E. R., Herzog, M. P., Hooper, S. L. and Smith, Z. (2011) Winter habitat associations of diurnal raptors in California's Central Valley. Western Birds 42: 62-84.

Petit, L. J., Petit, D. R., Christian, D. G. and Powell, H. D. W. (1999) Bird communities of natural and modified habitats in Panama. Ecography 22: 292-304.

Poulet, A. R. (1985) The ecological basis of forecasting rodent outbreaks in a Sahelian agrosystem. Acta Zool. Fennica 173: 107-111.

Preston, C. R. (1990) Distribution of raptor foraging in relation to prey biomass and habitat structure. Condor 92: 107-112.

Remsen, J. V. Jr., Swan, M. M., Cardiff, S. W. and Rosenberg, K. V. (1991) The importance of the rice-growing region of south-central Louisiana to winter populations of raptors, waders, and other birds. J. Louisiana Ornith. 1: $35-47$.

Rodríguez-Estrella, R., Donázar, J. A. and Hiraldo, F. (1998) Raptors as indicators of environmental change in the scrub habitat of Baja California Sur, Mexico. Conserv. Biol. 12: 921-925.

Sánchez-Zapata, J. A. and Calvo, J. F. (1999) Raptor distribution in relation to landscape composition in semiarid Mediterranean habitats. J. Appl. Ecol. 36: 254-262.

Scholte, P. T. (2003) Immigration: a potential time bomb under the integration of conservation and development. AMBIO: J. Human Envir. 32: 58-64.

Scholte, P. T. (2005) Flood plain rehabilitation and the future of conservation and development: adaptive management of success in Waza-Logone, Cameroon. $\mathrm{PhD}$ thesis. Leiden University, the Netherlands.

Scholte, P. T., Kirda, P., Saleh, A. and Kadiri, B. (2000) Flood plain rehabilitation in North Cameroon: Impact on vegetation dynamics. Appl. Veg. Science 3: 33-42.

Sergio, F., Newton, I., Marchesi, L. and Pedrini, P. (2006) Ecologically justified charisma: preservation of top predators delivers biodiversity conservation. J. Appl. Ecol. 43: 1049-1055.

Sergio, F., Caro, T., Brown, D., Clucas, B., Hunter, J., Ketchum, J., McHugh, K. and Hiraldo, F. (2008) Top predators as conservation tools: ecological rationale, assumptions, and efficacy. Ann. Rev. Ecol. Evol. Syst. 9: 1-19.

Sheffield, L. M., Crait, J. R., Edge, W. D. and Wang, G. (200I) Response of American kestrels and gray-tailed voles to vegetation height and supplemental perches. Can. J. Zool. 79: 380-385.

Thiollay, J.-M. (1977) Distribution saisonnière des rapaces diurnes en Afrique occidentale. O.R.F.O. 47: 253-285.

Thiollay, J.-M. (1978) Les plaines du nord Cameroun: centre d'hivernage de rapaces Palearctiques. Alauda 46: 319-326.

Thiollay, J.-M. (1989) Distribution and ecology of Palearctic birds of prey wintering in West and Central Africa. Pp. 95-107 in B.-U. Meyburg and R. D. Chancellor, eds. Raptors in the modern world. Berlin, Germany: WWGBP.

Thiollay, J.-M. (2001) Long-term changes of raptor populations in northern Cameroon. J. Raptor Res. 35: 173-186.

Thiollay, J.-M. (2006) The decline of raptors in West Africa: long-term assessment and the role of protected areas. Ibis 148: $240-$ 254.

Thiollay, J.-M. and Clobert, J. (1990) Comparative foraging adaptations of small raptors in a dense African savanna. Ibis 132: 42-57.

Thomas, L., Laake, J. L., Rexstad, E., Strindberg, S., Marques, F. F. C., Buckland, S. T., Borchers, D. L., Anderson, D. R., Burnham, K. P., Burt, M. L., Hedley, S. L., Pollard, J. H., 
Bishop, J. R. B. and Marques, T. A. (2006) Distance 6.o Release Beta 1. St. Andrews, UK: Research Unit for Wildlife Population Assessment, University of St. Andrews.

WCMC (World Conservation Monitoring Centre) (1983) Http://www.biologie.uni-hamburg. de/b-online/afrika/wcmc/waza.htm [accessed 25 December 2011].

Zwarts, L., Bijlsma, R. G., Van der Kamp, J. and Wymenga, E. (2009) Living on the edge. Wetlands and birds in a changing Sahel. Utrecht, the Netherlands: KNNV Uitgeverij.

\section{RALPH BUIJ*1, BARBARA M. CROES}

Institute of Environmental Sciences, Leiden University, PO Box 9518, 2300 RA Leiden, The Netherlands.

${ }^{1}$ also Behavioural Ecology and Self-organization, Centre for Ecological and Evolutionary Studies, University of Groningen, Centre for Life Sciences, Nijenborgh 7, 9747 AG Groningen, The Netherlands.

*Author for correspondence; email: ralph.buij@gmail.com

Received 17 May 2012; revision accepted 5 June 2012; Published online 8 April 2013 